\title{
RECENT DEVELOPMENTS IN STATE POWER TO REGULATE AND TAX INTERSTATE COMMERCE
}

\section{By Wallace Mendelson $\dagger$}

Within three years of his death Harlan Fisk Stone's judicial efforts to define the permissible extent of state encroachment upon interstate commerce have been abandoned by the Supreme Court. The late Chief Justice's "cumulative burden" rule for fixing the limits of local taxation of interstate transactions has been dismissed as a mere "fashion" in judicial utterance. ${ }^{1}$ Now with Hood v. DuMond ${ }^{2}$ his restatement of the Cooley rule ${ }^{3}$ for determining the permissible scope of state business regulation vis-a-vis the commerce clause seems to have been discarded.

In the absence of relevant national action is there a residuum of local power to govern matters of local concern which affect commerce among the several states? If there is such a residuum, what is the judiciary's role, if any, in defining its scope? These are hardy perennials of constitutional litigation in federal systems of government.

Chief Justice Marshall thought the commerce power was exclusively national, ${ }^{4}$ though he had trouble holding that position. ${ }^{5}$ For his successor, Chief Justice Taney, it was concurrent. The mere grant to Congress "cannot upon any principles of construction be construed to be an absolute prohibition to the exercise of any power over the same subject by the states." It followed that state regulations of interestate commerce were valid "unless they come into conflict with a law of Congress." 6 Under either view the courts would have little, if any, field of operation. But when the views of the two Chief Justices found uneasy reconciliation in the "selective exclusivity" rule of the Cooley case and its offshoots ${ }^{7}$ the Supreme Court became umpire in the most critical area of federal relationhips.

Any doctrinal compromise of the positions of Marshall and Taney would involve difficulties of application at best. Those difficulties were compounded when some judges found in the compromise a tempt-

$\dagger$ Associate Professor of Political Science, University of Tennessee.

1. Freeman v. Hewit, 329 U. S. 249, 254 (1946).

2. 336 U. S. 525 (1949).

3. Cooley v. The Board of Wardens, 12 How. 298 (U. S. 1851).

4. See, for example, his language in Gibbons v. Ogden, 9 Wheat. 1, 185-220 (U. S. 1824) and Brown v. Maryland, 12 Wheat. 419,446 (U. S. 1827).

5. See Willson v. Blackbird Marsh Creek Co., 2 Peters 244 (U. S. 1829), discussed below.

6. The License Cases, 5 How. 504, 578 (U. S. 1847).

7. As to the off-shoots see Mr. Justice Black, dissenting in Hood v. DuMond, 336 U. S. 525,545 (1949). 
ing vehicle for laissez-faire. By $1927 \mathrm{Mr}$. Justice Stone, dissenting with the concurrence of Justices Holmes and Brandeis, protested that

. . . the traditional test of the limit of state action by inquiring whether the interference with commerce is direct or indirect seems to me too mechanical, too uncertain in its application, and too remote from actualities, to be of value. In thus making use of the expressions, "direct" and "indirect interference" with commerce, we are doing little more than using labels to describe a result rather than any trustworthy formula by which it is reached. ${ }^{8}$

Clearly here was an issue to be recanvassed after the judicial "revolution" of 1937. Mr. Justice Black, dissenting, fired the first shots. $\mathrm{He}$

. . would return to the rule that-except for state acts designed to impose discriminatory burdens on interstate commerce because it is interstate-Congress alone "must determine how far . . . [interstate commerce] . . . shall be free and untrammeled, how far it shall be burdened by duties and imposts, and how far it shall be prohibited." 9

Stone for the Court took up Black's challenge in what for a while were leading cases in both the tax and regulatory fields.

\section{State Regulations Affecting Interstate Commerce}

Chief Justice Stone's response to Black's "leave-it-to-Congress" rule where states seek to regulate national commerce came in Southern Pacific Co. v. Arizona. ${ }^{10}$ There an Arizona law, limiting the length of all trains within the state, was challenged as a violation of the dormant commerce clause. Writing for a majority, the Chief Justice observed that "Reconciliation of the conflicting claims of state and national power" is attainable only by "appraisal and accommodation of the competing demands of the state and national interests involved." In the silence of Congress, "this Court, and not the state legislature is the final arbiter" between state and nation. That has been "accepted constitutional doctrine" for some hundred years. As arbiter the Court must decide whether the "relative weights of the state and national interests involved" are enough to overcome the rule that "the free flow of interstate commerce and its freedom from local restraint in matters requiring uniformity of regulation are interests safe-

8. DiSanto v. Pennsylvania, 273 U. S. 34, 44 (1927).

9. Gwin, White \& Prince v. Henneford, 305 U. S. 434, 455 (1939). See also Black's opinion in Adams Manufacturing Co. v. Storen, 304 U. S. 307 (1938).

10. 325 U. S. 761 (1945). 
guarded" by the unexercized commerce clause. This language obviously echoes the Cooley rule, but with a new emphasis-which Stone's careful weighing of the evidence makes clear-upon the "facts," rather than upon "labels."

Justices Black and Douglas dissented. In their view courts should intervene only where state legislation discriminates against interstate commerce or is not in harmony with national legislation. Moreover, according to Black,

This new pattern of trial procedure makes it necessary for a judge to hear all the evidence offered as to why a legislature passed a law and to make findings of fact as to the validity of those reasons. If under today's ruling a court does make findings, as to a danger contrary to the findings of the legislature, and the evidence "lends support" to those findings, a court can then invalidate the law. In this respect . . . this Court today is acting, as a "super-legislature." 11

The theoretical foundations of Stone's and Black's positions clearly stemmed from different conceptions of the Court's role in our federal system. But in practical result there was little to choose between them in business regulatory cases. Both positions resulted in a generous view of state power. Indeed the Southern Pacific case is the only one in which these differences in theory led to differences in outcome. It is also the only one prior to Hood v. DuMond in which "the Roosevelt Court" outlawed a local business regulation by virtue of the dormant commerce clause.

But with Hood v. DuMond all that for the time recedes into history. The new fashion in regulatory cases seems to be a throw-back to Chief Justice Marshall's position in Willson v. Blackbird Marsh Creek $\mathrm{Co}^{12}$ There the State of Delaware had authorized construction of a dam which completely obstructed commerce on a navigable stream. Observing that the state's purpose was the improvement of health and enhancement of property values, "the great Chief Justice" (without any concessions to the principle of the non-exclusiveness of the national commerce power) found scope for state regulations of a "police" nature which affect, here prohibit, interstate commerceas though state regulation of commerce were one thing and state exercise of the police power something. quite different. ${ }^{13}$ Here probably is the first use of the police power as what Mr. Justice Holmes called "converiient apologetics."

11. Id. at 788 .

12. 2 Peters 244 (U. S. 1829).

13. The hollowness of this conceptualism is analyzed by Chief Justice Taney in the License Cases, 5 How. 504, 583 (U. S. 1847). 
In the Hood case petitioner was engaged in supplying Boston with fluid milk procured in New York State. It operated two receiving plants in New York to which milk was delivered by the local producers and whence it was shipped without processing to Boston. In 1946 petitioner applied to the appropriate New York authorities for a license to operate a third receiving plant. The license was denied after an administrative finding that it "would tend to a destructive competition in a market already adequately served, and would not be in the public interest." Hood argued, inter alia, that refusal of the license was an undue interference with national commerce.

Mr. Justice Jackson, for a five man majority, upheld Hood's position without any reference to the Cooley or Southern Pacific cases, or the principles upon which they stood. Similarly silent as to the Blackbird Marsh Creek case, he turns the decision upon the

distinction betwen the power of the State to shelter its people from menaces to their health or safety and from fraud, even when those dangers emanate from interstate commerce, and its lack of power to retard, burden or constrict the flow of such commerce for their economic advantage . . . ${ }^{14}$

For Justices Black and Murphy in dissent the Court had set up "a new constitutional formula for invalidation of state law regulating local phases of interstate commerce." Black, for all his dislike of the Cooley-Southrn Pacific "balancing-of-interests" principle was prepared to support it as against the new "mechanistic formula" which struck down the New York Act "by a mere automatic application." Black's own preference as revealed in his past opinions is for an equally "mechanistic formula" which would "by a mere automatic application" uphold state legislation in the silence of Congress and the absence of discrimination against interstate commerce. ${ }^{15}$ These are the two extreme positions-reversions in effect to Marshall and Taney (though the latter apparently would not with Black make an exception for discrimination cases).$^{18}$ One reads prohibition, the other permission, in the silence of Congress. In either case the role of the Court is greatly simplified. Black's diagnosis that the "balancingof-interests" principle makes a super-legislature of the judiciary apparently is now adopted by the Court, but his cure is rejected in favor of a rule which puts "the inertia of government [i.e., Congress]

14. Hood v. DuMond, 336 U. S. 525, 533 (1949).

15. Black apparently has abandoned the fight for this and is willing to accept the balancing-of-interests principle. See $i d$. at 553 , note 4 .

16. See Frankfurter, The Comarerce Ciause 54 (1937). 
. . . on the side of freedom of commerce" 17 rather than upon the side of freedom for state legislative policy as Black would have it.

When hope for obtaining a majority for the latter position had to be abandoned Mr. Justice Douglas, who with Black and Murphy had been its constant advocate, switched to the opposite extreme by joining the Hood majority. That was entirely logical, if the real objection to "balancing-of-interests" was that it made the Court a super-legislature. Black's willingness in the Hood case to accept the middle, or "balancing-of-interests" position, suggests greater concern for freedom of state legislative policy than for the purity of the judicial process. His linguistic concern for the latter in the past may have been at least partly tactical. ${ }^{18}$ In any case Black's new position is grounded largely upon his fear that

the new formula. . . will not merely leave a large area of local business activities free from state regulation. All local activities that fall within the scope of this new formula will be free from any regulatory control whatever. For it is inconceivable that Congress could pass uniform national legislation capable of adjustment and application to all the local phases of interstate activities that take place in the 48 states. . . .

The judicially directed march of the due process philosophy as an emancipator of business from regulation appeared arrested a few years ago. That appearance was illusory. That philosophy continues its march. ${ }^{18}$

Mr. Justice Frankfurter, dissenting with Rutledge, would have remanded the case for findings that would permit judicial balancingof-interests in the manner of Stone's Southern Pacific opinion. He could not "agree in treating what is essentially a problem of striking a balance between competing interests as an exercise in absolutes." 20 For Frankfurter "the basic function of this Court [is to act] as mediator of powers within the federal system." 21 The late Chief Justice doubtless would have rated that function second only to the safeguarding of civil liberty. Accordingly, neither of them could go along with the "mechanistic" formulas of either the new Jackson or the old Black.

17. The quotation is from Jackson's concurring opinion in Duckworth v. Arkansas, 314 U. S. 390, 400 (1941), where the Hood majority position is foreshadowed.

18. For example, Frankfurter's preoccupation with the purity of the judicial process is well known. It is interesting that Black apparently had Frankfurter in his camp in McCarroll v. Dixie Greyhound Lines, 309 U. S. 176 (1940), and then lost him.

19. Hood v. DuMond, 336 U. S. 525, 545, 562 (1949).

20. Id. at 564 .

21. West Va. Bd. of Education v. Barnette, 319 U. S. 624, 667 (1943). 
In Freeman v. Hewit Frankfurter, speaking for a majority, had made the point that

A Police regulation of local aspects of interstate commerce is a power often essential to a State in safeguarding vital local interests. . . . State taxation, falling on interstate commerce on the other hand, can only be justified as designed to make such commerce bear a fair share of the cost of the local government whose protection it enjoys. To deny to a State a particular source of income because it taxes the very process of interstate commerce does not imply a crippling limitation on a State's ability to carry on its local function. . . . ${ }^{22}$

Accordingly, he said, the Court has always rightly "scrutinized and resisted" state taxation more carefully than state regulation in interstate commerce cases. A majority in the Hood case now in effect abandons that distinction and the relatively greater latitude which it implies for state regulation as against taxation by narrowly limiting state regulatory power to "health or safety . . . and fraud" situations.

If the Hood case has meaning beyond settlement of the immediate questions there at issue, it indicates abandonment of the ninetyeight year old Cooley doctrine-hitherto an unquestioned landmark in constitutional law. It is a switch from an $a d$ hoc, mediatory weighing of national and local claims to "health, safety and fraud" as the touchstone of state regulatory power affecting commerce among the several states. The static, pristinely dictionary, sense in which Jackson uses the words "health," "safety" and "fraud" in the Hood case indicates a much restricted area of state competence, as well as a change in the Court's conception of its function in federalism casesfrom mediation to adjudication.

\section{State Taxation Affecting Interstate Commerce}

At the first opportunity after "reconstruction" of the Court in 1937 Mr. Justice Stone, for a majority, recanvassed the whole troubled problem of the effect of the unexercised commerce power upon state taxation. Some state tax measures had been upheld, some had not:

The vice characteristic of those which have been held invalid is that they have placed on the commerce burdens of such nature as to be capable, in point of substance, of being imposed . . . or added to . . . with equal right by every state which the commerce touches, merely because interstate commerce is being

22. 329 U. S. 249,253 (1946). 
done, so that without the protection of the commerce clause, it would bear cumulative burdens not imposed on local commerce . . . [the present tax] finds support in reason, and in the practical needs of a taxing system which, under constitutional limitations, must accommodate itself to the double demand that interstate business shall pay its way, and that at the same time it shall not be burdened with cumulative exactions which are not similarly laid on local business. ${ }^{23}$

Mr. Justice Black's response to this new "cumulative burden" rule came in a lone dissent in Gwin White \& Prince, Inc. v. Henneford. ${ }^{23 a}$ There the state of Washington had imposed a "business license" tax on the gross receipts of a local firm whose business consisted in marketing Washington and Oregon fruit in several states and foreign countries. The Court held the measure invalid:

If Washington is free to exact such a tax, other states to which the commerce extends may, with equal right, lay a tax similarly measured for the privilege of conducting within their respective territorial limits the activities there which contribute to the service. The present tax, though nominally local, thus in its practical operation discriminates against interstate commerce, since it imposes upon it merely because interstate commerce is being done, the risk of a multiple burden to which local commerce is not exposed. ${ }^{24}$

Black dissented on the ground that multiple taxation here was purely "hypothetical" because under the majority view, as he saw it, no other states could tax such transactions for exactly the same reasons which prevented Washington from doing so. It followed that, since local business was taxable and interstate business was everywhere exempt, the former not the latter suffers the burden of discrimination. But for Black these are essentially legislative problems:

Only a comprehensive survey and investigation of the entire national economy - which Congress alone has power and facilities to make - can indicate the need for, as well as justify, restricting the taxing power of a State so as to provide against conjectural taxation by more than one State on identical income. A broad and deliberate legislative investigation-which no Court can make-may indicate to Congress that a wise policy for the national economy demands that each State in which an interstate business operates be permitted to apply a non-discriminatory tax to the gross receipts of that business either because of its size and volume or partially to offset the tendency toward centralization

23. Western Livestock v. Bureau of Revenue, 303 U. S. 250, 255-256, 258 (1938). 23a. 305 U. S. 434 (1939).

24. Id. at 439. 
of the nation's business. Congress may find that to shelter interstate commerce in $\mathrm{a}_{\text {. tax }}$ exempt refuge-in the manner of the judgment here-is to grant that commerce a privileged status, over intrastate business, contrary to the national welfare. ${ }^{25}$

As though in answer to Black's observation that it was really local business which was being discriminated against (because of immunities afforded interstate commerce), the majority in the "revolutionary" McGoldrick $v$. Berwind-White ${ }^{26}$ decision permitted the state at the buyer's end of an interstate sale to impose a sales, or gross receipts, tax. Mr. Justice Stone, for the Court, observed that:

Non-discriminatory taxation of the instrumentalities of interstate commerce is not prohibited . . . it was not the purpose of the commerce clause to relieve those engaged in interstate commerce of their just share of state tax burdens, merely because an incidental or consequential effect of the $\operatorname{tax}$ is an increase in the cost of doing business . . . (The present tax) is conditioned upon events occurring within the state, either transfer of title or possession of the purchased property, or an agreement within the state, "consummated" there, for the transfer of title or possession. ${ }^{26 a}$

Hughes, McReynolds and Roberts objected that this was taxation of interstate commerce of a kind long since outlawed.

Black (with Douglas and Murphy) had no trouble in going along with the majority for the language was sufficiently broad to justify similar taxation in the seller's state as well, which Black had been urging all along as justifiable in the absence of discrimination or Congressional action. It fell to Mr. Justice Frankfurter after Stone's death to dispell any illusions which Black, Douglas, and Murphy might have had on that score. In Freeman v. Hewit, ${ }^{27}$ speaking for a majority, he struck down another gross income tax in the seller's state. Stone's line was held, but the departed Chief Justice's "cumulative burden" language was dismissed as merely a "fashion" in judicial utterance. The new fashion, which sounds quite old to some, is to speak in terms of the "directness" of the tax upon interstate commerce -a fashion which Frankfurter there indulges at least ten times to explain his result.

The return to the "directness" doctrine is condemned as a return to formalism. But it is difficult not to see the same "formalism" in Stone's efforts. As Professor Powell has observed the "revolutionary" Berwind

25. Id. at 449 .

26. 309 U. S. 33 (1940).

26a. Id. at $43-47$.

27. 329 U. S. 249 (1946), Black, Douglas and Murphy dissenting. 
White case added not a whit to state taxing power. ${ }^{27 a}$ It nierely permitted the buyer's state "to impose a sales tax without calling it a use tax." But in Stone's hands the "cumulative burden" rule prohibited only the more general sales, or gross receipts, taxes imposed by the seller's state upon interstate transactions. It did not interfere with slightly more specialized taxes called something else, for example, "privilege taxes" upon an interstate publishing business measured by receipts from the sale of advertising. ${ }^{28}$ To save himself from the logic of his own cumulative burden language Stone fell back upon the "direct" burden approach.

So far as the advertising rates reflect a value attributable to the maintenance of a circulation of the magazine interstate, we think the burden on the interstate business is too remote and too attenuated to call for a rigidly logical application of the doctrine that gross receipts from interstate commerce may not be made the measure of a tax. . . Here it is perhaps enough that the privilege taxed is of a type which has been regarded as so separate and distinct from interstate transportation as to admit of different treatment for purposes of taxation. . . . The dangers which may ensue from the imposition of a tax measured by gross receipts derived directly from interstate commerce are absent. ${ }^{29}$

Similarly it was only the tour de force prohibiting a sales tax in the seller's state which removed the cumulative burden objection to a sales tax in the buyer's state-a purely arbitrary choice (so far as the Constitution is concerned) as between the two possibilities. Yet Stone justified the buyer's state sales tax without admitting the tour de force, by pretending, as in the advertising case, that the taxable event was a local occurrence "separated" from the total interstate transaction. Indeed Stone's language and method in the Berwind-White (buyer's state) case would apply equally in the seller's state cases-it is merely a matter of "separating" a local incident of an interstate activity and ignoring its organic economic relation to the whole transaction.

As we have already seen, for Stone and Frankfurter a basic function of the Supreme Court is to act as "arbiter" (Stone) or "mediator" (Frankfurter) in the federalism area where national and state interests conflict and Congress is silent. For present purposes this means balancing on an ad hoc basis the claim that interstate com-

27a. Powell, New Light on Gross Receipts Taxes, 53 Harv. L. Rev. 909 (1940). 28. Western Livestock v. Bureau of Revenue, 303 U. S. 250 (1938). Note also how the majority including Stone uses "directness" language in J. D. Adams Mfg. Co. v. Storen, 304 U. S. 307, 312 (1938) to distinguish American Mfg. Co. v. St. Louis, 250 U. S. 459 (1919) which like the Western Livestock case certainly opened the door to cumulative tax burdens.

29. Western Livestock v. Bureau of Revenue, 303 U. S. 250, 259-260 (1938). 
merce should pay its own way against the claim for protection of the national market from Balkanization. Stone's historical contribution was to counteract the emphasis which the Court had been giving the Balkanization claim-but he did not deny that claim's importance. Historical context explains Stone's linguistic emphasis upon freedom for state taxation, but he remained an arbiter, a balancer, of two mutually hostile claims. When the facts of a particular case threw the arbitral scales one way he resorted to "local incident," or "directness" language or even to a tour de force to permit state taxation. When the scales indicated a threat of Balkanization he resisted state taxation on cumulative burden grounds. As Stone, himself, put it:

Experience has taught that the opposing demands that the commerce shall bear its share of local taxation, and that it shall not on the other hand, be subjected to multiple tax burdens merely because it is interstate commerce, are not capable of reconciliation by syllogism. Practical rather than logical distinctions must be sought. ${ }^{30}$

Frankfurter as mediator balances the same demands on the same ad hoc, "practical," basis, but prefers to do so under the single mantle of the directness language-the cumulative burden approach deceptively suggesting both precision and ventures into the economics of tax incidence not contemplated even by its author.

Frankfurter, who since Stone's death seems to be the center around which a majority coagulates in federalism tax cases, found his foil in Mr. Justice Rutledge. In a lengthy separate opinion in the Hervit case Rutledge stated his own position and condemned both Stone's and Frankfurter's approaches, though he agreed with their results. Rutledge brings out into the open Stone's tour de force (confining sales taxation to the buyer's state) ; acknowledges it as constitutionally arbitrary though economically justifiable, but condemns Stone's Berzeind-White "local incidence" rationalization for it." For Rutledge the real criteria-the proper language-was neither "directness," nor "local incidence," but "the risk of multiple state taxation." 32 Since all three Justices agree in the fiat that sales taxes may be imposed only in the buyer's state, the dispute is purely one of terminology

30. Western Livestock v. Bureau of Revenue, 303 U. S. 250, 259 (1938). The foregoing analysis resolves, for example the inconsistency which Magill, Stone on Taxation, 46 CoL. L. REv. 747, 755 (1946), finds in Stone's positions in the Western Livestock case, supra, and Fisher's Blend Station v. Tax Commission, 297 U. S. 650 (1936).

31. Id. at 270-271, 278, 280-281. Rutledge would refine the tour de force by permitting the seller's state to impose a sales tax provided it allows a credit for any sales tax due or paid in the buyer's state. Id. at 279.

32. Id. at 272. 
in sales tax cases. Not so in cases involving other types of state taxation! Interstate Oil Pipe Line Co. $v$. Stone, ${ }^{33}$ the latest case on the subject, illustrates the practical difference between the Rutledge and Stone-Frankfurter positions. There appellant operated a pipe line entirely within Mississippi for the transportation of oil from the oil fields to railroad tank cars as the first leg in a certain and immediate trip from the Mississippi oil fields to refineries in other states. Mississippi sought to impose "annual privilege taxes" upon appellant's "gross income."

For Rutledge (with Black, Douglas and Murphy) the tax was permissible since it

does not discriminate against interstate commerce in favor of competing intrastate commerce of like character. The nature of the subject of taxation makes apportionment unnecessary; there is no attempt to tax activity carried on outside Mississippi's borders. No other state can repeat the tax. ${ }^{34}$

Mr. Justice Burton in a separate opinion, finding that appellant's activities did not constitute interstate commerce, concurred in Rutledge's result, but expressly repudiated his reasoning. Accordingly the tax was upheld over the dissents of Frankfurter, Reed, Jackson and the Chief Justice who objected on "directness" grounds.

The process which begins with the extraction of crude oil from the ground in Mississippi, moves on through a refinery in Louisiana and terminates in the consumption of gasoline, etc., let us say, in Tennessee, is an organic economic process. For Rutledge, though he condemns "multiple state taxation" of interstate commerce, any state along the way may tax that process without apportionment provided it selects an incident, however indispensable to the completion of the whole process, which occurs entirely within the taxing state. Mississippi may tax the transportation within Mississippi; ${ }^{35}$ Louisiana may tax the equivalent of stevedoring when the oil is unloaded at the Baton Rouge refinery; ${ }^{36}$ Tennessee may tax the sale to the consumer at Knoxville ${ }^{37}$ - to mention only propositions to which Rutledge expressly assented. It follows that the "directness" rule gives greater protection against multiple state taxation of interstate commerce than the "multiple tax"

33. 69 S. Ct. 1264 (1949). See also case cited in note 36, infra.

34. Id. at 1267.

35. Ibid. Frankfurter, Reed, Jackson and Vinson dissenting.

36. Joseph v. Carter \& Weeks Stevedoring Co., 330 U. S. 422 (1947) which, over the dissents of Rutledge, Douglas, Murphy and Black, invalidated on "directness" grounds a gross receipts tax on a stevedoring company engaged wholly within New York in loading vessels engaged in interstate and foreign commerce.

37. McGoldrick v. Berwind-White Coal Co., 309 U. S. 33 (1940), the result of which Rutledge approves, Freeman v. Hewit, 329 U. S. 249, 273 (1946). 
rule. $^{38}$ No wonder that Black, Douglas and Murphy, who as in the regulatory cases have given up the fight for "leave it to Congress," found a refuge with Rutledge. Except in the sales tax cases the "multiple tax" rule in effect "leaves it to Congress."

One final problem. What is the status of Hereit in view of $D u$ Mond? The "directness" rule of the former obviously entails judicial weighing of conflicting state and national interests on an $a d$ hoc, case to case basis. Does DuMond, coming after Hewit, foreshadow its demise in favor of a "mechanistic formula"-Rutledge's perhaps-for tax cases comparable to that apparently established by DuMond for regulation cases? Presumably not, for in Interstate Oil Pipe Line Co. v. Stone which came after DuMond the Justices were divided four to four between the "multiple taxation" and "directness" rule. Burton threw the decision Rutledge's way, not because he agrees with the "multiple tax" rule, but because in that particular case he did not find interstate commerce involved. Since Burton has joined in the Hezeit position on earlier occasions ${ }^{39}$ where he conceived interstate commerce to be involved, one concludes that $D u M$ ond does not alter the majority status of Hewit. If the conceptionalism of Commerce Power versus Police Power is to rule in regulation cases, ad hoc mediation (under the cloak of the "directness" formula) still dominates in the settlement of state tax claims upon national commerce.

38. Cf. Independent Warehouse, Inc. v. Scheele, 331 U. S. 70 (1947).

39. In addition to the Hewit case itself, see, for example, Joseph v. Carter \& Weeks Stevedoring Co., 330 U. S. 422 (1947). 